Published on-line first in Comparative European Politics (2018)

Https://doi/org/10.1057/s41295-018-0142-1

\title{
Populism and Ethno-Territorial Politics in European Multilevel Systems
}

Reinhard Heinisch, Emanuele Massetti and Oscar Mazzoleni

Available at: https://link.springer.com/article/10.1057\%2Fs41295-018-0142-1

Reinhard Heinisch

Department of Political Science

University of Salzburg

A-5020 Salzburg, Rudolfskai 42

Tel.:0043(0)662 8044-6615

reinhard.c.heinisch@sbg.ac.at

Emanuele Massetti

Department of Politics

University of Surrey

Guildford, GU2 7XH

Surrey, UK

Tel. +44 (0)1483684385

e.massetti@surrey.ac.uk

Oscar Mazzoleni

Institute of Political, Historical and International Studies

University of Lausanne

Bâtiment Géopolis

CH-1015 Lausanne

Tel. +41 (0)21 6923635

oscar.mazzoleni@unil.ch

(corresponding author) 


\section{Abstract}

The relationship between populism and ethno-territorial politics has emerged repeatedly in empirical studies outside Western Europe. This article presents the main aim of the special issue, which is the systematic and empirically based investigation of the linkages between populism and ethno-territorial ideologies in Western European states. By introducing a conceptual map, in which the defining characteristics of populism, regionalism, statenationalism, and Euroscepticism are identified and conceptualized, the article proceeds with the possible linkage points between both concepts. It also proposes a smallest common denominator relationship between populism and ethno-territorial ideologies in that the notion of 'homogeneous people' becomes inexorably connected to the concept of 'nation' or 'region' pitted against political, economic, and cultural elites operating at various levels of government. By foreshadowing and discussing several of the key findings of the empirical case studies presented in this special issue, the introductory article highlights important emerging trends. Most crucially, only radical-right parties (both regionalist and state-nationalist) appear to be inherently and stably populist. The same parties are also clearly Eurosceptic. By contrast, several regionalist parties, positioned in the mainstream left or right, tend to adopt a populist discourse only incidentally and temporarily.

Keywords: Populism, Regionalism, Nationalism, Euroscepticism, Centre/Periphery, Ethnic politics, Multilevel Politics 


\section{Introduction}

The scholarship on populism outside Western Europe has often identified center-periphery dynamics and ethno/racial diversity as strictly linked to populist mobilizations. Centreperiphery dynamics have featured prominently both in Northern and Latin America. In the US, until very recently, populism has been primarily identified as the expression of malcontent of the (communitarian) deep Mid-West and/or South against the (liberal) 'Coastal elites' (Pollak, 1962; Nugent, 1963; Palmer, 1980; Carter, 1996; Savage, 2012). In Canada, populist movements of different ideological orientations have primarily emerged in the Western peripheries in contraposition to the elites of 'Central Canada' (Conway, 1979; Laycock, 1990; Nevitt, 1998). For long time, populism in Latin America was primarily conceived as a macroeconomic strategy - i.e., Import Substitution Industrialization (Dornbush and Edwards, 1991) — aimed to cope with the peripheral position of that world region vis-à-vis the centers of the world economy (i.e. US and Western Europe). In addition, in more recent studies, a clear centre-periphery dynamic has been identified within and across individual states; for instance in the relationship between the Andean mountain areas and the plains (Dunkerley, 2007). Similarly, ethnic and racial diversity has featured prominently in the study of populism in the US, in Latin America, in India and in Central-Eastern Europe (Carter, 1995; Lowndes, 2008; Madrid, 2008; Webber, 2011; Pantnaik and Chalam, 1996; Bugaric, 2008).

However, since the scholarship of party politics in Western Europe has been deeply shaped by 'methodological nationalism' (Jeffery and Wincott, 2010), the literature on populist parties has taken the nation-state as the natural context of analysis, systematically downplaying sub-state ethno-territorial instances. Centre-periphery dynamics have been given scant attention and have popped up in the literature only incidentally: when the main interpreters of populism in a given country, such as the Vlaams Belang in Belgium and the Northern League in Italy, where 
also regionalist (or minority nationalist) parties (Pauwels, 2011; McDonnell, 2006; Biorcio, 2017). As for ethnic diversity, this has been pointed out as strongly related to (right-wing) populism but almost exclusively in regard to xenophobic and/or racist claims against immigrants (Van der Brug et al., 2000; Rydgren, 2003; 2005; 2008; Albertazzi and McDonnell, 2008). In contrast, the link between populism and ethnic divisions within the 'native' populations has remained largely unexplored in the Western European context.

Finally, while the scholarship has widely investigated the relationship between populism and Euroscepticism (Taggart, 1998; Krouwel, 2007; Ruzza, 2009; Harmsen, 2010; Tournier-Sol, 2015), the study of such relationship has only focused on two levels — national and EU—with extremely rare works analyzing the multi-level (i.e. regional-national-EU) dynamics of the populism/Euroscepticism nexus (Mazzoleni, 2005).

This special issue aims to directly address these lacunae within the scholarship, by investigating center-periphery relationships, ethnic cleavages and multi-level dynamics that impact upon or are informed by populist politics in Western Europe. This article opens the special issue, providing a conceptual map and an explorative comparative analysis of the relationship and linkages between populism, regionalism (or minority nationalism), majority ethno-nationalism and Euroscepticism.

In the next section, we introduce, discuss, and define the concept of populism. This is followed by a segment devoted to conceptualizing and defining specific ethno-territorial ideologiesregionalism, majority nationalism, and Euroscepticism-and highlighting the potential linkages between each of them and populism. We, then, present several ideological combinations that are reflected in the cases analyzed in the articles of this special issue. We further discuss these combinations in the final section of this introductory article.

\section{Populism: Between thin ideology and discourse}


Many studies on populism tend to stress the difficulty of the scholarship to agree on a clear definition of the underlying concept (Berlin, Hofstadter and MacRae, 1968; Canovan, 1981; Taguieff, 1995; Taggart, 2000). Leaving aside the loose use of the term made by the media (Bale at al., 2011), two main factors can be held responsible for conceptual slipperiness or disagreement in the academic debate. First, the predominance of single case-studies or region specific studies - e.g., Latin American (Di Tella, 1965; De la Torre, 2010), Northern American (Kazin, 1998; Berlet and Lyons, 2000), Western Europe (Betz, 1994; Taggart, 1995; Rooduijn et al., 2014; Heinisch and Mazzoleni, 2016; Akkerman, T. et al., 2017), Central-Eastern Europe (Mudde, 2000; Minkenberg, 2002; Vujacic, 2003; Pirro, 2014), etc.- often ignoring contributions coming from other regional-comparative studies (De la Torre, 2018). Second, a certain tendency to shift the discussion from the essence of the concept of populism to the conceptual category to which populism belongs: whether populism is an ideology (Mudde, 2004; Stanley, 2008), a discourse (Laclau, 1977; 2005; Rooduijn and Powels, 2011), a frame (Aslanidis, 2016; Heinisch and Mazzoleni 2017) or a strategy (Wayland, 2001; Jansen, 2011). However, digging beneath the surface, it is possible to identify a certain substantive convergence in how populism is conceived in the recent international scholarship (Panizza, 2005; De la Torre, 2015; Müller, 2016; Mudde and Kaltwasser, 2017). Indeed, the distinction between strategy, discourse and frame is more superficial than substantive, given that proponents of 'populism as a strategy' include also 'populist rhetoric' (i.e. 'discourse') as a defining element of that strategy (Jansen, 2011: 83). As for the distinction between ideology and discourse, this is typically reduced by the very advocates of 'populism as an ideology' to that of a 'thin ideology' (Stanley, 2008). The distance between the two positions can be called into question even further by the fact that Michael Freeden himself (the 'father' of the 'thin ideology ${ }^{1}$ concept) has expressed doubt about populism even qualifying as an ideology at all, 
even a thin one (Freeden, 2017). Instead, he appears to argue in favor of populism's borderline nature in-between (thin) ideology and discourse (Freeden, 2017: 10).

If Freeden's contribution helps us reach an acceptable middle ground in the debate on the conceptual category containing the phenomenon of populism, a certain 'center of gravity' has emerged based on the definition proposed amongst others by Cas Mudde and consisting of the following components: a) a vision of society as divided in two groups, the 'pure people' and the 'corrupt elites'; b) the internal homogeneity of the two groups; c) the antagonistic relationship between the two groups; and d) always siding with the 'pure people' as the only legitimate source of the 'general will' (Mudde, 2004: 543). These defining criteria, advanced by a key proponent of 'populism as an ideology' are to some extent compatible with most definitions proposed by advocates of 'populism as a discourse' such as Laclau (2005) and Rooduijn and Powels (2011) as well as the advocates of 'populism as a strategy' such as Jansen (2011).

Other important elements emphasized by several authors, such as a sense of crisis (Taggart, 2000; Rooduijn, 2014), can actually be considered contextual conditions under which a populist discourse may be more viable or successful (Kriesi and Pappas, 2015). By contrast, other recurring elements such as the stigmatization of 'dangerous others' (Albertazzi and McDonnell, 2008) may be better understood as 'linkage nodes' to other (thick or thin) ideologies, such as in the connection between populism and the radical right (Betz, 1994; Rydgren, 2005). Indeed, populism can be linked with very different ideological orientations from radical left to radical right; from inclusionary to exclusionary; from socialist to neoliberal; from secular to religious; from fanaticism for charismatic leadership to fanaticism for grassroots democracy (Otjes and Louwerse, 2015; March, 2017).

The fact that populism can connect with completely different (and even contrasting) ideological orientations is also due to its intrinsic ambivalence (Taggart, 2000; Heinisch and Mazzoleni 
2017). Populist claims are, by definition, ambivalent because the key concepts of populism are not sufficiently defined: 'the people' are depicted as a homogeneous and amorphous group generally without differences of interest and class. In fact, the way populists conceive of the group making up the 'elites' may be even more vague and entirely situational. Therefore, ambivalence may be considered as a key characteristic of populism, providing strategic flexibility and adaptability as well as a major source of diffusion of populist discourse among political actors. This means that, while there are parties for which populism represents their core ideology/discourse, it is much more likely to find parties that engage in a populist discourse informed by a different (more or less well defined) ideological position, or parties that forge a synthesis between populism and another ideology.

Since, this special issue is concerned with the linkages between populism and the ethnoterritorial (thin) ideologies, particular attention is devoted to recognizing which ideological/discursive elements in the empirical cases are distinctively populist, which ones come from ethno-territorial ideologies and what the linkage nodes are. This will allow distinguishing, for instance, between primarily populist parties engaging with regionalist claims and primarily regionalist parties using a populist discourse. It will also allow for the exploration of how the populist actors cope with the challenges arising from the ambivalence rooted in their often contradictory ideological patchwork, e.g. populism and regionalism and state-nationalism. We now turn to introducing the key ideological elements of regionalism, majority (or state) nationalism, and Euroscepticism, thus completing the conceptual map that we set out to provide.

\section{Ethno-territorial ideologies and their potential links with populism}




\section{Regionalism}

Regionalism can be defined as a thin ideology that politicizes the specificities of the population living in a certain sub-state region vis-à-vis the population of the state as a whole (Fitjar, 2010). These specificities, which can be socio-cultural (language, religion, prevailing ideological orientations, etc.) and/or socio-economic (type and level of economic development, prevalent economic sectors, economic status of the region vis-à-vis the rest of state, etc.), are seen as the bases of a separate ethno-territorial identity which should be formally recognized and accommodated by the state. Indeed, regionalist parties are defined as those self-contained political organizations that focus on the protection/enhancement of regional identities and interests, challenging the central state with their requests for some kind of territorial selfgovernment (De Winter, 1998; Massetti, 2009; Alonso, 2012; Mazzoleni and Mueller, 2017). The level of self-government claimed by regionalist parties can vary considerably. In this respect, Massetti and Schakel (2016) have identified a crucial distinction between those regionalist parties that pose a threat to the territorial integrity of the state ('secessionist') and those that do not ('autonomist'), highlighting how regionalist parties can change their claims over time. In addition, Dandoy (2010) has highlighted much more stable differences within the 'secessionist' category, distinguishing between 'independentist', 'irredentist', and 'rattachist' parties.

Adopting a different terminology, some scholars prefer to distinguish between 'regionalist' and 'stateless nationalist' (or 'minority nationalist') parties (Hepburn, 2009; Elias, 2009). However, the distinction seems to defy a persuasive definition and, in the end, the little value added by this distinction is attested by the fact that the very proponents consider both regionalist and stateless nationalist parties as belonging to one same party family (Hepburn, 2009). We, therefore, treat stateless (or minority) nationalism as an internal sub-category of regionalismdenotating those cases in which a claim to nationhood is made- bearing in mind that it does 
not necessarily coincide with the sub-category of secessionism. Like populism, regionalism can (and does) also combine itself with all sorts of ideological orientations, from the radicalleft to the radical-right (Massetti, 2009; Massetti and Shakel, 2015). The linkages with populism can happen therefore within a broader ideological outlook.

The most basic and most evident connection between regionalism and populism resides in the potential correspondence between the two foundational dichotomies: 'people vs. elites' can be equated to 'region (or minority nation) vs. state' and vice versa. In the regionalist-populist synthesis, the 'good people' are the people in the region, while the elites are the politicians defending state interests at the expenses of the regional population. Regionalist populists typically focus on the putative incapacity or unwillingness of national elites in the far away capital to recognize, understand, and even consider the specific needs of the region. As highlighted by Taggart (2000), populist discourse often refers to a lost 'heartland'. Indeed, the politics of resentment and victimization, so typical of populism, might resonate well with ethno-regional minorities that perceive a lack of recognition or fair treatment of their region by the state elites. Given the structural antagonism between regionalist parties and the (statewide parties') politicians that run the state, we can expect to find this minimal level of populist discourse in virtually all regionalist parties. Similarly, we can expect a regional populist party, or a particularly autonomous regional branch of a statewide populist party, to back-up their criticism of elites with a regionalist discourse. It is worth pointing out that both regionalist and populist parties can antagonize not only the state political elites but, where a regional government is in place, also the regional political elites. Whether the regionalist populist synthesis will target only the state elites or both the regional and state elites, will depend primarily on the role of the party in the regional and national party system (fringe party, relevant but not in office, relevant and in office, hegemonic and continuously in office) and by 
the age/history of the party (new/old; history of co-operation/competition with statewide parties).

Besides this basic connection, populism and regionalism can combine within the frame of a broader ideological orientation. In these cases, the political actors forging the regionalist populist synthesis may target not only (or not primarily) political elites but also economic and/or intellectual elites. In addition, regionalist populists can target not only regional and state elites but also supra-national and international ones (Mazzoleni, 2005). In Laclau's terms (2005), they can challenge what they perceive as the dominant elite discourse from different ideological standpoints - e.g., challenging a dominant liberal/tolerant/pluralist discourse from a radical-right standpoint, or a dominant neoliberal/economic conservative discourse from a radical left standpoint, etc.).

Special mention should be made of a particular category of regionalist parties-unionist regionalist parties - that operate in ethnically divided regions and often find themselves fighting on two fronts. These parties are as much assertive advocates of a distinct regional identity and regional self-government as they are staunch supporters of state territorial integrity against other ethno-regionalist (potentially or openly secessionist) movements/parties that have claims on the same region (Massetti, 2009: 504). In a way, like all regionalist parties, they are in a bargaining (and sometimes confrontational) relationship with the state for attaining a certain degree of self-government. At the same time, they fully side with the state against secessionist threats involving their region and mobilize people based on alternative ethnoregional identities. It should be noted that highly autonomous regional branches of a statewide parties can also engage in this type of two-front battles. Indeed, some of these parties can enter into close agreements with (majority nationalist) statewide parties, thus becoming de-facto their regional branches - e.g., the agreements between the Ulster Unionist Party (UUP) and the British Conservative Party in Northern Ireland and between Union of Navarrese People (UPN) 
and the Spanish People's Party in Navarra. If in such cases, parties make use of a populist discourse, then the ambivalence, as to who 'the people' really are, can become even blurrier. When they act as regionalist parties, 'the people' are likely to be (a particular ethnic group or) the regional population. If they act as regional agents of majority (state) nationalism, 'the people' will probably coincide with the majority (state) nation.

\section{State (or Majority) Nationalism}

Nationalism is widely considered as a thin ideology which prioritizes national divisions over other political issues and promotes the own nation vis-à-vis other nations (Freeden, 1998). State nationalism is the ideology at the basis of the (putative) nation-state: the nation is presented as the social pre-requisite and justification for the state; while the latter is seen as the political/institutional instrument of the former. If the nation-state project is not internally contested, state nationalism remains an implicit or dormant ideology. If the nation-state project is internally contested, different scenarios open up, depending primarily on the level of democracy of the political system and on the mobilization strategies of ethno-regionalist forces. Advanced liberal democracies tend of acknowledge the legitimate presence of ethno-regional identities that are uneasy with a strict pursuit/upholding of the nation-state project. Within the resulting democratic dialectic, some political forces can voice their resistance against this pluralist revision of the nation-state project. Therefore, in these cases, state nationalism remains a particularly potent force in the form of majority nationalism. ${ }^{2}$ The main concern of majority nationalists is the mobilization of ethno-territorial identities by regionalist parties/movements. In particular, majority nationalists tend to target ethno-territorial minorities that are perceived as a threat to national integrity, either because of their own strength or because there are protected/supported by a neighboring (kin) state. In theory, majority nationalist parties can have different ideological orientations along the left-right continuum. However, in the context 
of liberal democracies, parties situated on the right of the political spectrum-particularly conservative and radical-right parties - tend to engage more with majority nationalism. Therefore, the populist-nationalist synthesis tends to manifest itself as a form of right-wing populism (Loch, 2017).

The most obvious linkage between majority nationalism and populism may be found in the identification of the (majority) nation as 'the good people', intended as a homogeneous group that does not allow internal (ethno-territorial) differentiation (Muller, 2016): either a person/group is in or is out of the 'nation-people'. So, while the main 'enemies' of majority nationalist are the regionalist (particularly secessionist) political forces, in their populistnationalist synthesis the targeted elites are the national parties and cultural elites that are perceived to be softer vis-a-vis regionalist claims. Accusations made against these elites (which might include also international or supra-national elements) may range from being insufficiently assertive/resolute in protecting the unity and integrity of the nation-state to a full betrayal of the nation-state. It goes without saying that, beyond fighting against mobilized ethno-regional identities, majority nationalist parties also want to protect the national identity from the supposed threats posed by immigrant communities. In this case, their majority nationalism and exclusivist/xenophobic nativism results in the adoption of a radical-right ideology (Mudde, 2007). The populist radical-right synthesis thus presents the 'good people', understood as the majority/native nation (to the exclusion of ethno-territorial minorities and immigrant communities), against the 'corrupt elites', understood as those (pluralist and multiculturalist) political forces that do not protect (or work against) the homogeneity/purity of the nation. $^{3}$

\section{Euroscepticism}


State nationalism is not only concerned with internal threats to the integrity of the nation-state. It can also aim outward and upward by identifying international and/or supra-national actors that are accused of conspiring against the interests of the nation-state and depriving the nationpeople of their sovereignty. In this case, the linkage with populism is rather immediate because the influence of external elites (usually helped by internal elites) is seen as diminishing the people's sovereignty. While general 'sovereignism' tends to target the main actors of globalization — such as transnational economic elites and international institutions (e.g., the World Bank and the International Monetary Fund) — in Europe sovereigntist political forces tend to direct their recriminations against European integration and its creature, the European Union (EU). Euroscepticism can be seen, therefore, as a particular case of sovereignism and, in turn, a particular expression of state nationalism.

Scholarship has identified different degrees and forms of Euroscepticism. The Sussex school distinguishes between 'soft' and 'hard' Euroscepticism, whereby the former is defined as a qualified criticism of some EU policies (or integration in some policy areas) and the latter as an outright claim against EU membership (Taggart, 1998; Szczerbiak and Taggart, 2008). In contrast, Kopecky and Mudde (2002) distinguish between political forces that oppose the very idea of European integration (Eurorejects) and those that, albeit supporting the principle of European integration, openly criticize the way in which it has been actualized (Eurosceptic).

Like the other ethno-territorial ideologies, Euroscepticism can, in theory, combine itself with all types of leftist and rightist ideologies. In fact, empirical studies have found that Euroscepticism tends to connect itself primarily with radical-left and radical-right ideologies (Hix, 1999; Hooghe et al., 2002). In particular, hard and/or principled Euroscepticism tends to be found primarily among radical-right parties (Vasilopoulou, 2011; 2018) whereas radicalleft parties tend to manifest primarily forms of criticism for the way the EU has been shaped (e.g. its allegedly neo-liberal ethos). 
Regionalist parties also pay a lot of attention to European integration, as the latter considerably affects the opportunity structure of the former (Jeffery, 2000; Keating, 2004). Although most regionalist parties have generally been supportive of European integration (De Winter and Gomez-Reino, 2002; Jolly, 2015), Eurosceptic positions have become more common in the last two decades (Elias, 2008). As for the relationship between Euroscepticism and other ideological orientations, regionalist parties tend to follow the same pattern as statewide parties: radical-right and radical left regionalist parties tend to be more Eurosceptic than mainstream regionalist parties (Massetti, 2009).

Since the process of European integration follows a project devised by supranational elites, it is virtually self-evident why Euroscepticism can be easily expressed through a populist discourse: national sovereignty, which guarantees the democratic representation of the interests and identity of the people-nation, is seen as sacrificed by supranational elites in favor of Brussels' centralizing tendencies against the will of the people (Taggart, 1998; Harmsen, 2010; Fabbrini, 2017).

Given the additional (supranational) level of governance in the EU, European political parties -whether regional or statewide - have the opportunity to engage in 'multi-level populism' (Mazzoleni, 2005). This means that due to tactical or strategic considerations, some populist parties can shift the meaning of 'good people' and 'corrupt elites' depending on specific conditions, such as the pattern of competition and the position within government (in office or in opposition).

\section{Case-studies of the special issue: emerging patterns}

The special issue consists of six empirical articles focusing on the linkages between populism and ethno-territorial politics in ten political parties across seven Western European states. Four 
articles analyze regionalist parties: Massetti's comparison between Plaid Cymru-The Party of Wales (Plaid) and the Scottish National Party (SNP) in the UK; van Haute, Sinardet and Pauwels' comparison between DeFI and Vlaams Belang (VB) in Belgium; Mazzoleni and Ruzza's comparison between the Lega dei Ticinesi and Lega (Nord) in Switzerland and Italy; and Barrio, Barbera and Rodriguez-Teruel's study of the Catalan secessionist parties, Convergencia Democratica de Catalunya - Partit Democrata Europeo Catala (CDC-PDCAT) and Esquerra Republicana de Catalunya (ERC), which together with two secessionist movements formed, in 2015, the electoral coalition Junts pel Si (JxSi) in the Spanish region. Two articles analyze state nationalist parties: Heinisch and Marent's work on the Freiheitliche Partei Österreichs (FPÖ) in Austria; and Ivaldi and Dutozia's study of the Front National (FN) in France.

At first sight, there might seem a full overlap between the territorial organization of parties and their ethno-territorial ideology. This because regionalist parties are also regional, in the sense that their party organization is present only in a specific territory and they compete in elections only in that territory (or ethno-linguistic community in the case of Belgium) within the state; while state nationalist parties operate statewide. However, looking more closely, this is not exactly the case. On the one hand, the regionalist Northern League (since December 2017 only League) has often tried to compete electorally also in regions where the party organization was absent and is currently trying to build up a statewide party organization (Mazzoleni and Ruzza, in this issue). On the other hand, the state-nationalist FN has clearly adapted its discourse to different French regions (Ivaldi and Dutozia, in this issue). In addition, the FPÖ has openly engaged in unionist regionalism as its Carinthia's regional branch adopted a confrontational stance vis-a-vis Vienna while at the same time targeting the Slovene ethnic minority in the region (Heinisch and Marent, in this issue). The articles show very clearly that these partial mismatches between party settlement and ethno-territorial ideology, as well as the taking up of 
potentially conflicting ethno-territorial ideologies (e.g., state nationalism and regionalism) entails both opportunities and vulnerabilities, requiring a sophisticated management of political communication across the different levels of government. In addition, engagement with multiple ethno-territorial ideologies also leads to top significant ambivalence, particularly as to who the 'good people' really are and on whom the populist discourse is focused (Mazzoleni and Ruzza, in this issue; Heinisch and Marent, in this issue).

As for the parties' ideological position along the left-right dimension, seven of them are placed right of the center, while three are positioned left of the center. The latter are all regionalist and mainstream left parties (Plaid, SNP and ERC). In contrast, amongst the seven rightist parties, only two are mainstream right (the regionalist DeFI and CDC-PDCAT), while five are antiimmigrant radical-right parties: three regionalists (VB, LN and LT) and two state nationalists (FPÖ and FN). Interestingly, the five radical-right parties are the only ones adopting a marked form of Euroscepticism (van Haute et al., in this issue; Mazzoleni and Ruzza, in this issue; Heinisch and Marent, in this issue; Dutozia and Ivaldi, in this issue). Two of them, the state nationalist FN and FPÖ, criticize the EU primarily in the interest of their respective nationstate. One of them, the regionalist VB, attacks the EU primarily in the interest of the Flemish region (and the Dutch-speaking community). Finally, two of them, the regionalist Italian League and the Swiss League of Ticino, voice their Euroscepticism alternating (and trying to reconcile) a defense of regional and national interests.

From the following articles, it emerges that the parties analyzed and their relationship with populism varies considerably. The latter may be considered an essential and stable feature only in the five radical-right (and Eurosceptic) parties (VB, LN, LT, FPÖ and FN). By contrast, populism is virtually absent in the liberal regionalist DeFI (van Haute et al., in this issue) while regionalist parties in Catalonia and in the Celtic peripheries of Britain have adopted a populist discourse only temporarily. In particular, Catalan regionalist parties have used populism in 
their recent shift to a secessionist stance, which emphasized the right of self-determination of the Catalan people vis-à-vis Spanish elites (Barrio et al., in this issue); while the SNP and Plaid have engaged, since 2010, in a form of left-wing populism that, targeting the pro-austerity British elites, resembles Southern European populism in the context of the Euro crisis (Massetti, in this issue).

Summing up, this article intended to conceptualize the relationship between populism and ethno-territorial politics in Western Europe. Its aim is the systematic and empirical analysis of the linkages between the two key concepts as well as of the different formations and their operating logic that engage in both populism and ethno-territorial claims. While we find a conceptual common denominator in equating the 'the people' with some concept of ethnos and territory and their antagonistic relationship with elites both internal and external to the territory in question, the analysis also reveals that the relationship between populism and ethnoterritorial politics is varied and complex. The systematic mapping introduced here is intended as a conceptual basis for further empirical research demonstrations of which are provided in the following case studies.

\section{References}

Akkerman, T. et al. (eds) (2017) Radical right-wing populist parties in Western Europe: into the mainstream? London: Routledge.

Albertazzi, D. and McDonnell, D. (eds.) (2008) Twenty-First Century Populism. New York: Palgrave Macmillan.

Alonso, S. (2012) Challenging the State: Devolution and the Battle for Partisan Credibility. Oxford: Oxford University Press. 
Aslandis, P. (2016) Is Populism an Ideology? A Refutation and a New Perspective. Political Studies 64(1): 88-104.

Bale, T., van Kessel, S., and Taggart, P. (2011) Thrown around with abandon? Popular understandings of populism as conveyed by the print media: a UK case study. Acta Politica 46(2): 111-131.

Berlet, C., Lyons, N. M. (2000) Right-wing Populism in America. Too close for Comfort. New York: The Guilford Press.

Berlin, I., Hofstadter, R., and MacRae, D. G. (1968) To define Populism. Government and Opposition 3(1): 137-179.

Betz, H-G. (1994) Radicalism and Right-wing populism in Western Europe. New York: St. Martin's Press.

Biorcio, R., (2017) The Northern League. In: Mazzoleni, O. and Mueller, S. (2016) (eds) Regionalist Parties in Western Europe: Dimensions of Success. London: Routledge, pp. 135-151.

Bugaric, B. (2008) Populism, liberal Democracy, and the Rule of Law in Central and Eastern Europe. Communist and Post-Communist Studies 41(1): 191-203.

Canovan, M. (1981) Populism. New York and London: Harcourt Brace Jovanovich.

Carter, D. T. (1995) The Politics of Rage: George Wallace, The Origins of the New Conservatism, and the Transformation of American Politics. New York: Simon \& Schuster.

Carter, D. T. (1996) From George Wallace to Newt Gingrich. London: Louisiana State University Press.

Conway, J. F. (1979) The Prairie Populist Resistance to the National Policy: Some Reconsiderations. Journal of Canadian Studies 14(3): 77-91. 
Dandoy, R. (2010) Ethno-regionalist parties in Europe: a typology. Perspectives on Federalism 2(2): 194-220.

De Winter, L. (1998) Conclusion: a comparative analysis of the electoral, office and policy success of ethnoregionalist parties. In De Winter, L. and H. Tursan (eds) Regionalist Parties in Western Europe. London: Routledge, pp. 190-235.

De Winter, L. and Gomez-Reino, M. (2002) European integration and ethnoregionalist parties. Party Politics 8(4): 483-503.

De la Torre, C. (2010) Populist Seduction in Latin America. Athens: Ohio University Press.

De la Torre, C. (ed.) (2014) The Promise and Perils of Populism: Global Perspectives Lexington: The University Press of Kentucky.

De la Torre, C. (ed.) (2018) Routledge Handbook of Global Populism. Abingdon: Routledge.

Di Tella, T. S. (1995) Populism. In Lipset, S. M. (ed.) The Encyclopedia of Democracy. vol. 3. London: Routledge.

Dornbush, R. and Edwards, S. (eds) (1991) The Macroeconomics of populism in Latin America. Chicago: University of Chicago.

Dunkerley, J. (2007) Evo Morales, the 'Two Bolivias' and the Third Bolivian Revolution. Journal of Latin American Studies 39(1): 133-166.

Elias, A. (2008) From Euro-enthusiasm to Euro-scepticism? A Re-evaluation of Minority Nationalist Party Attitudes Towards European Integration. Regional and Federal Studies 18 (5): 557-581. 
Fabbrini, F., 2017, The Euro-Crisis, EMU and the Perils of Centralisation. In Daniele L., Simone P., Cisotta R. (eds.) Democracy in the EMU in the Aftermath of the Crisis. Cham: Springer, pp. 121-140.

Fitjar, R.D. (2010) The Rise of Regionalism: Causes of regional mobilization in Western Europe. Oxon: Routledge.

Freeden M. (2017) After the Brexit Referendum: revisiting Populism as an Ideology, Journal of Political Ideologies 22(1): 1-11.

Harmsen, R. (2010) Concluding Comment: On Understanding the Relationship between Populism and Euroscepticism, Perspective on European Politics and Society 11(3): 333341.

Heinisch, R., Mazzoleni, O. (2017) Analysing and Explaining Populism: Bringing Frame, Actor and Context back in. In Heinisch, R., Holtz-Bacha, C., Mazzoleni, O. (eds.) Political Populism. A Handbook. Baden-Baden: Nomos, pp. 105-122.

Hepburn, E. (2009) Introduction: Re-conceptualizing sub-state mobilization. Regional and Federal Studies 19 (4-5): 477-499.

Hix, S. (1999) Dimensions and alignments in European Union politics: cognitive constraints and partisan responses. European Journal of Political Research 35(1): 69-106.

Hooghe, L., Marks, G. and Wilson, C. (2002) Does left/right structure party positions on European integration? Comparative Political Studies 35(8): 965-989.

Jansen, R. S. (2011) Populist Mobilization: A New Theoretical Approach to Populism. Social Theory, 29(2): 75-96 
Published on-line first in Comparative European Politics (2018)

Https://doi/org/10.1057/s41295-018-0142-1

Jeffery, C. (2000) Subnational mobilization and European integration. Journal of Common Market Studies 38(1): 1-24.

Jeffery, C. and Wincott, D. (2010) The Challenge of Territorial Politics: Beyond Methodological Nationalism. In Hay, C. (ed) New Directions in Political Science. Basingstoke: Palgrave.

Jolly, K. S. (2015) The European Union and the Rise of Regionalist Parties, Ann Harbor, University of Michigan Press.

Kazin, M. (1998) The Populist Persuasion: An American History. Itacha: Cornell University Press.

Keating, M. (2004) European Integration and the Nationalities Question. Politics and Society 32(3): 367-388.

Kopecky, P. and Mudde, C. (2002) The two sides of Euroscepticism. Party Positions on European Integration in East central Europe, European Union Politics 3(3): 297-326.

Kriesi, H. and Pappas, S. T. (eds.) (2015) European Populism in the Shadow of the Great Recession. Colchester: ECPR Press.

Krouwel, A. (2007) Varieties of Euroscepticism and Populist Mobilization: Transforming Attitudes from Mild Euroscepticism to Harsh Eurocynicism. Acta Politica 42(2-3): 252270.

Laclau, E. (1977) Politics and Ideology in Marxist Theory. London: NLB.

Laclau, E. (2005) On Populist Reason. London: Verso.

Laycock, D. (1990) Populism and Democratic Thought in the Canadian Prairies, 1910 to 1945. Toronto: University of Toronto Press. 
Loch, D. (2017) Conceptualising the Relationship between Populism and the Radical Right. In Heinisch, R., Holtz-Bacha, C., Mazzoleni, O. (eds.) Political Populism. A Handbook. Baden-Baden: Nomos, pp. 73-86.

Lowndes, D. (2008) From the New Deal to the New Right: Race and the Southern Origins of Modern Conservatism. Dexter: Yale University Press.

Madrid, R. L. (2008) The Rise of Ethnopopulism in Latin America, World Politics, 60(3): 475508.

Massetti, E (2009) Explaining regionalist party positioning in a multi-dimensional ideological space: A framework for analysis. Regional and Federal Studies 19(4/5): 501-531.

Massetti, E. and Schakel, A. (2015) From Class to Region: How Regionalist Parties Link (and Subsume) Left-Right into Centre-Periphery Politics. Party Politics 21(6): 866-886.

Massetti, E. and Schakel, A. (2016) Between Autonomy and Secession: Decentralization and Regionalist party Ideological Radicalism. Party Politics 22(1): 59-79.

March, L. (2017) Left and Right Populism compared: The British Case. The British Journal of Politics and International Relations 19(2): 282-303

Mazzoleni, O. (2005) Multi-Level Populism and Centre-Periphery Politics Cleavage in Switzerland: The Case of the Lega dei Ticinesi. In Caramani, D. and Meny, Y. (eds) Challenges to Consensual Politics: Democracy, identity and Populist Protest in the Alpine Region. Brussels: Peter Lang, pp. 209-227.

Mazzoleni, O. and Mueller, S. (eds) (2016) Regionalist Parties in Western Europe: Dimensions of Success. London: Routledge.

McDonnell, D. (2006) A Weekend in Padania: Regionalist Populism and the Lega Nord. Politics 26 (2): 126-132. 
Minkenberg, M. (2002) The radical Right in post-socialist central and eastern Europe. East European Politics and Societies 16(2): 335-362.

Mudde, C. (2000) In the name of the peasantry, the proletariat and the people: Populisms in Eastern Europe. East European Politics and Societies 15(1): 33-53.

Mudde, C. (2007) Populist Radical Right Parties in Europe. Cambridge: Cambridge University Press.

Mudde. C. and Rovira Kalwasser, C. (2017) Populism. A very short Introduction. Oxford: Oxford University Press.

Müller, J-W. (2016) What's Populism. Philadelphia: University of Pennsylvania Press.

Nevitt, N. et al. (1998) The populist right in Canada: the rise of the Reform Party of Canada. In Betz, H-G. and Immerfal, S. (eds) The new Politics of the Right: Neo-Populist Parties and Movements in Established Societies. New York: St. Martin Press, pp. 173-202.

Nugent, W. T. K. (1963) The Tolerant Populists: Kansas Populism and Nativism. Chicago: University of Chicago Press.

Otjes, S., Louwerse, T. (2015) Populists in Parliament: Comparing Left-Wing and Right-Wing Populism in the Netherlands. Political Studies 63(1): 60-79.

Palmer, B. (1980) 'Man over Money': the Southern populist Critique of American Capitalism. Chapel Hill: University of North Carolina Press.

Panizza, F. (2005) Populism and the Mirror of Democracy. London: Verso.

Pauwels, Teun (2011) Measuring Populism: A Quantitative Text Analysis of Party Literature in Belgium. Journal of Elections, Public Opinion and Parties 21(1): 97-119. 
Pollak, M (1962) The populist Response to Industrial America: Midwestern Populist Thought. Cambridge: Harvard University Press.

Pantnaik, A. and Chalam, K. S. (1996) The ideology of Hindutva. In Sathyamurathy, T. V. (ed.) Reion, Religion, Caste, Gender and Culture in Contemporary India. Delhi: OUP.

Roodujin, M. (2014) The Nucleus of Populism: In Search of the Lowest Common Denominator. Government \& Opposition 49(4): 573-599.

Rooduijn, M., de Lange, S.L.van der Brug, W. (2014) A populist Zeitgeist? Programmatic contagion by populist parties in Western Europe. Party Politics 20(4): 563-575.

Rooduijn, M. and Pauwels, T. (2011) Measuring Populism: Comparing Two Methods of Content Analysis. West European Politics 34(6): 1272-1283.

Ruzza, C. (2009) Populism and Euroscepticism: Towards Uncivil Society? Policy and Society 28(1): 87-98.

Rydgren, J. (2003) Meso-level Reasons for Racism and Xenophobia: Some Converging and Diverging Effects of Radical Right Populism in France and Sweden. European Journal of Social Theory 6(1): 45-68.

Rydgren, J. (2005) Movements of Exclusion: Radical Right-Wing Populism in the Western World. New York: Nova.

Rydgren, J. (2008) Immigration sceptics, xenophobes or racists? Radical right-wing voting in six West European countries. European Journal of Political Research 47(6): 737-765.

Savage, R. (2012) From McCarthyism to the Tea Party: Interpreting Anti-Leftist Forms of US Populism in Comparative Perspective. New Political Science 34(4): 564-584. 
Szczerbiak, A. and Taggart, P. (eds) (2008) Opposing Europe? Comparative and Theoretical Perspectives. Volume II. Oxford: Oxford University Press.

Taggart, P. (1995) New Populist Parties in Western Europe. West European Politics 18(1): 3451.

Taggart, P. (1998) A Touchstone of Dissent: Euroscepticism in Contemporary Western European Party Systems. European Journal of Political Research 33(3): 363-388.

Taggart, P. (2000) Populism. Buckingham: Open University Press.

Taguieff, P-A. (1995) Political Science Confronts Populism: From a Conceptual Mirage to a Real Problem. Telos 103: 9-43.

Tournier-Sol, K. (2015) Reworking the Eurosceptic and Conservative Traditions into a Populist Narrative: UKIP's Winning Formula? Journal of Common Market Studies 53(1): 140-156.

van der Brug, W. et al. (2000) Anti-immigrant parties in Europe: Ideological or protest vote? European Journal of Political Research 37(1): 77-102.

Vasilopoulou, S. (2011) European Integration and the Radical Right: Three Patterns of Opposition. Government and Opposition 46(2): 223-244.

Vasilopoulou, S. (2018) Far Right Parties and Euroscepticism. Patterns of Opposition, London, Ecpr Press/ Rowman \& Littlefield.

Vujacic, V. (2003) From Class to Nation. East European Politics and Societies 17(3): 359-392.

Weyland, K. (2001) Clarifying a Contested Concept: Populism in the Study of Latin American Politics. Comparative Politics 34(1): 1-22. 
Webber, J. R. (2011) From rebellion to reform in Bolivia: Class struggle, indigenous liberation, and the politics of Evo Morales. Chicago: Haymarket Books.

Zuber, C. and Szocsik, E. (2018) The Second Edition of the Expert Survey on Ethnonationalism in Party Competition - Testing for Validity and Reliability. Regional and Federal Studies, first-online, pp. 1-23.

Word length: 6300

20 May 2018

\footnotetext{
${ }^{1}$ Freeden actually uses the expression 'thin-centered ideology' to stress the limited coverage of the core component of some ideologies - such as feminism, environmentalism and nationalism - vis-à-vis the main ideologies - liberalism, socialism and conservatism (Freeden, 1996; 1998).

${ }^{2}$ It is worth noting that the ethno-demographic conditions of some countries (e.g. Belgium or Bosnia) make it extremely difficult to establish which group represents majority nationalism (Zuber and Szocsik, 2018).

${ }^{3}$ In countries where ethno-regional minorities are virtually absent (e.g. Germany or Denmark) or relatively scarcely mobilized (e.g. France or the Netherlands), populist radical-right parties are only concerned with immigrant communities.
} 